\title{
Application of BDq method to complex tropical mixed forest ecosystems in Nigeria
}

Friday Nwabueze OGANA ${ }^{1}$

José Javier GoRgOSO-VARELA

Alfred Ossai ONEFELI ${ }^{3}$

${ }^{1}$ University of Ibadan

Department of Social and Environmental

Forestry

Ibadan

Nigeria

${ }^{2}$ University of Santiago de Compostela Campus de Lugo

Lugo

Spain

${ }^{3}$ University of Ibadan

Department of Forest Production

and Products

Ibadan

Nigeria

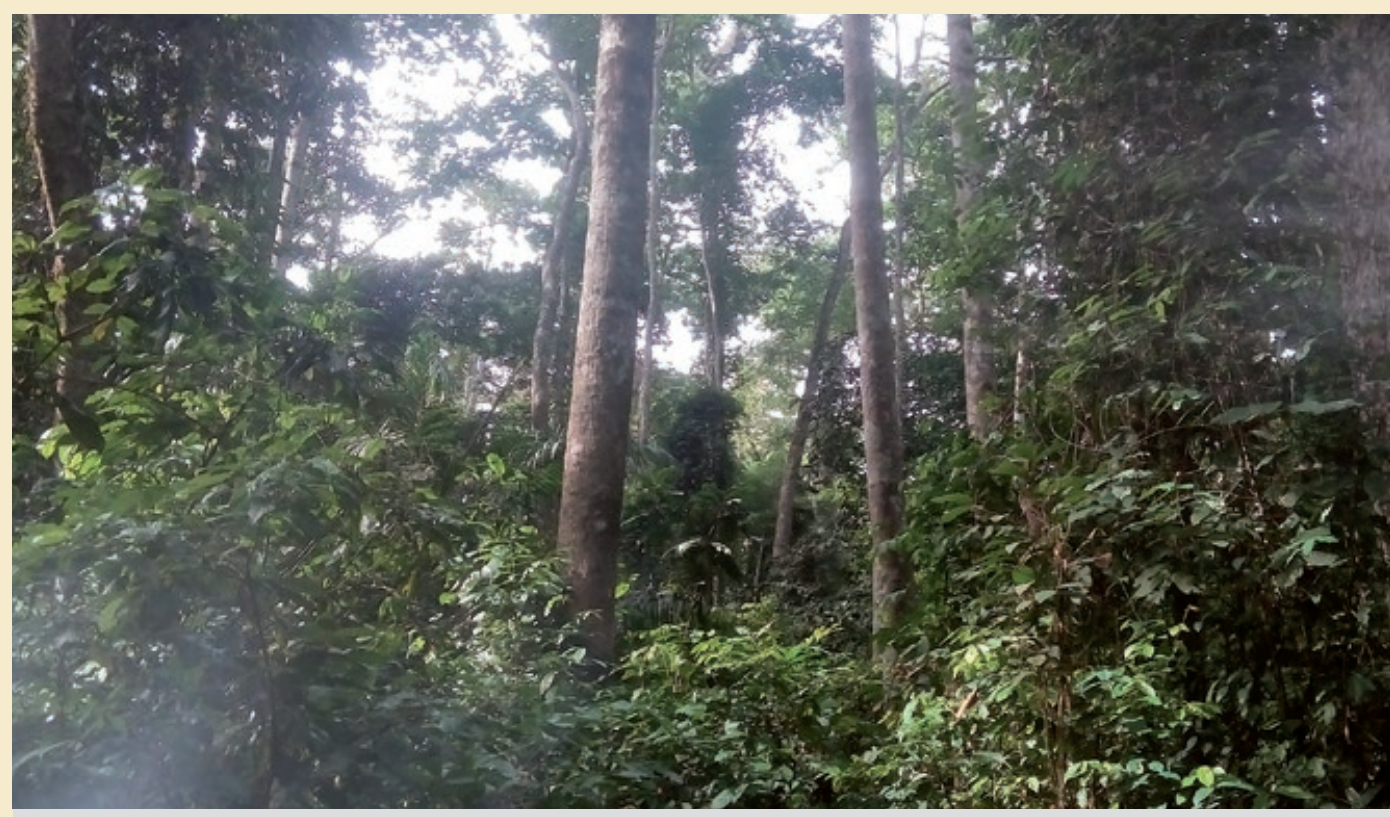

\section{Auteur correspondant /}

Corresponding author:

Friday Nwabueze OGANA -

Photo 1.

Tropical mixed forest ecosystem in Nigeria.

Photo F. N. Ogana.

fn.ogana@ui.edu.ng

Doi : 10.19182/bft2021.349.a36779 - Droit d'auteur ( 2021, Bois et Forêts des Tropiques - (c) Cirad - Date de soumission : 10 décembre 2020 ; date d'acceptation : 5 mai 2021 ; date de publication : $1^{\text {er }}$ septembre 2021.

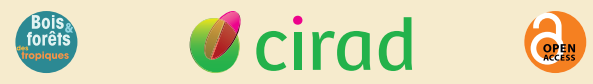

(c) (1)
Citer l'article / To cite the article

Ogana F. N., Gorgoso-Varela J. J., Onefeli A. O., 2021. Application of BDq method to complex tropical mixed forest ecosystems in Nigeria. Bois et Forêts des Tropiques, 349 : 37-50. Doi : https://doi.org/10.19182/ $\underline{b f t 2021.349 .036779}$ 


\section{RÉSUMÉ}

\section{Application de la méthode $B D q$ dans les écosystèmes tropicaux à forêt mixte complexe au Nigeria}

L'absence de pratiques de gestion et de traitements sylvicoles dans les forêts tropicales mixtes complexes du Nigeria conduit à leur exploitation incontrôlée et au déclin de leur biodiversité. Pour assurer le maintien de la production, de la protection et de la conservation de ces peuplements mixtes complexes, la présente étude propose l'application d'une méthode de sélection, dite méthode $B D q$ ( $B$ : surface terrière ; $D$ : diamètre maximal ; q-ratio) pour leur gestion. Un essai pilote a porté sur deux strates, comportant 15 parcelles pour la strate 1 et 7 parcelles pour la strate 2, chacune avec une superficie de 0,25 ha. Seuls les arbres avec un diamètre à hauteur de poitrine $D \geq 10,0 \mathrm{~cm}$ ont été pris en compte pour cette étude. La récolte de bois avec la méthode $B D q$ a été quantifiée selon l'intensité d'exploitation, avec $B$ à $20 \mathrm{~m}^{2}, 25 \mathrm{~m}^{2}$ et $30 \mathrm{~m}^{2} /$ ha correspondant respectivement à un régime intensif, modéré et peu intense, pour un diamètre $D$ à $65 \mathrm{~cm}$. Le $q$-ratio a été calculé pour chacune des parcelles. Les résultats montrent que les trois régimes $B D q$ prescrits (intensif, modéré et peu intense) permettent des intensités d'abattage (FI) raisonnables, en pourcentage du volume extrait $\left(\mathrm{V}_{\text {ex }}\right)$ et de la biomasse $\left(\mathrm{W}_{\text {ext }}\right) . \mathrm{V}_{\text {ext }}$ et $\mathrm{FI}$ pour la strate 1 varient entre 39,94$62,30 \mathrm{~m}^{3} /$ ha et $11,22-18,18 \%$ et entre $30,44-51,33 \mathrm{~m}^{3} /$ ha et $10,02-17,57 \%$ pour la strate 2 . Pour la biomasse, $\mathrm{W}_{\text {ext }}$ et $\mathrm{Fl}$ varient entre $18,46-29,82 \mathrm{t}$ / ha et $9,40-15,95 \%$ pour la strate 1 et entre $14,16-24,82$ t/ha et $9,73-17,50 \%$ pour la strate 2 . Ces constats indiquent que l'application de la méthode $B D q$ dans les forêts tropicales mixtes et complexes du Nigeria permettrait d'obtenir des peuplements intéressants.

Mots-clés : gestion sylvicole à couvert continu, peuplements forestiers naturels, surface terrière résiduelle, traitement sylvicole, bois, distribution de Weibull, Nigeria.

\section{ABSTRACT}

\section{Application of the $B D q$ method to complex tropical mixed forest ecosystems in Nigeria}

The absence of management practice/ silvicultural treatments in the complex tropical mixed forests of Nigeria has led to uncontrolled logging in natural forest stands and loss of biodiversity. To sustain production, protection and conservation in these complex tropical mixed stands, this study proposes the application of a selection method - the $B D q$ method ( $B$ : basal area, $D$ : maximum diameter, $q$-ratio) to manage these stands. Two strata were used as a pilot test: stratum 1 consisted of 15 plots and stratum 2 of 7 plots, each with an area of 0.25 ha. Only trees with a diameter at breast height $(\mathrm{d}) \geq 10.0 \mathrm{~cm}$ were considered in this study. Harvesting with the $B D q$ method was quantified, by setting $B$ at $20 \mathrm{~m}^{2}, 25 \mathrm{~m}^{2}$ and $30 \mathrm{~m}^{2} /$ ha corresponding respectively to heavy, medium and light harvesting regimes. $D$ was set at $65 \mathrm{~cm}$ and the $q$-ratio was computed for each plot. The results showed that the three $B D q$ regimes prescribed (heavy, medium and light) yielded reasonable felling intensities (FI), derived as the percentage of extracted volume $\left(\mathrm{V}_{\text {ext }}\right)$ and biomass $\left(\mathrm{W}_{\text {ext }}\right)$. The $\mathrm{V}_{\text {ext }}$ and $\mathrm{Fl}$ for stratum 1 ranged from 39.94$62.30 \mathrm{~m} 3 / \mathrm{ha}$ and $11.22-18.18 \%$; the results for stratum 2 were 30.44-51.33 $\mathrm{m}^{3} / \mathrm{ha}$ and $10.02-17.57 \%$. For biomass, the $\mathrm{W}_{\text {ext }}$ and $\mathrm{Fl}$ ranged from 18.46-29.82 t/ha and $9.40-15.95 \%$ for stratum 1 and 14.16-24.82 t/ha and 9.73-17.50\% for stratum 2. These findings show that applying the $B D q$ method to the complex tropical mixed forests of Nigeria would yield attractive stands.

Keywords: continuous cover forestry, natural forest stands, residual basal area, silvicultural treatment, timber, Weibull distribution, Nigeria.

\section{RESUMEN}

\section{Aplicación del método $B D q$ a los ecosistemas forestales mixtos tropicales complejos de Nigeria}

La ausencia de prácticas de gestión y tratamientos silvícolas en los complejos bosques mixtos tropicales de Nigeria ha provocado la tala incontrolada en las masas forestales naturales y la pérdida de biodiversidad. Con el objetivo de favorecer la producción, la protección y la conservación de estas complejas masas mixtas tropicales, este estudio propone la aplicación de un método de selección -el método $B D q$ ( $B$ : área basal, $D$ : diámetro máximo, ratio q) - para gestionarlas. Se utilizaron dos estratos como prueba piloto: el estrato 1 constaba de 15 parcelas y el estrato 2, de 7 parcelas, cada una con una superficie de 0,25 ha. En este estudio sólo se consideraron los árboles con un diámetro a la altura normal $(D) \geq 10,0 \mathrm{~cm}$. Se cuantificó el aprovechamiento maderero con el método $B D q$, fijando $B$ en $20 \mathrm{~m}^{2} / \mathrm{ha}, 25 \mathrm{~m}^{2} /$ ha y $30 \mathrm{~m}^{2} /$ ha, correspondientes respectivamente a los regímenes de cosecha intensiva, media y ligera. $D$ se fijó en $65 \mathrm{~cm}$ y se calculó el ratio $q$ para cada parcela. Los resultados mostraron que los tres regímenes de $B D q$ prescritos (intensivo, medio y ligero) dieron lugar a intensidades de tala $(\mathrm{Fl})$ razonables, derivadas del porcentaje de volumen extraído $\left(\mathrm{V}_{\text {exx }}\right)$ y de la biomasa extraída $\left(W_{\text {ext }}\right)$. El $V_{\text {ext }} y$ el Fl del estrato 1 obtenidos fueron de $39,94-62,30 \mathrm{~m}^{3} /$ ha y $11,22-18,18 \%$; los resultados del estrato 2 fueron de 30,44$51,33 \mathrm{~m}^{3} /$ ha y $10,02-17,57 \%$. En cuanto a la biomasa, el $\mathrm{W}_{\text {ext }}$ y el Fl obtenidos fueron de $18,46-29,82 \mathrm{t} /$ ha y $9,40-15,95 \%$ para el estrato 1 , y $14,16-24,82$ t/ha y $9,73-17,50 \%$ para el estrato 2 . Estos resultados muestran que la aplicación del método $B D q$ a los complejos bosques mixtos tropicales de Nigeria permitiría obtener producciones de masas forestales interesantes.

Palabras clave: silvicultura de cobertura continua, masas forestales naturales, área basal residual, tratamiento silvícola, madera, distribución de Weibull, Nigeria. 


\section{Introduction}

The tropical rain forest is one of the most diverse biomes of the world (Dupuy et al., 1999; Turner, 2001). It is characterised by multiple species composition and multi-layered structure (Temesgen et al., 2014). Such complex ecosystems provide a wider array of benefits and can address some ecological and environmental issues compared to monoculture stands (Schütz et al., 2012). To sustain production, protection and conservation in the tropical forest ecosystem, there is a need to adopt effective management practice(s). Up to the present time, there is little or no management practice/ silvicultural treatments in the complex tropical mixed forests of Nigeria. This is evidence in the uncontrolled exploitation of natural forest stands in the country.

A well-known management system that will ensure the sustainability of production, protection and conservation in the tropical mixed forest stand is Continuous Cover Forestry (CCF). CCF is a management system that is "characterised by selective harvesting and natural regeneration" (Schütz et al., 2012). Its operability is based on certain principles which include: continuous cover (avert large clear-felling), stability (sustain stable forest structure) and naturalness (biodiversity) (Davies et al., 2008). Mason et al. (1999) asserted that to ensure continuous cover, trees on stand $>0.25$ ha should not be completely harvested. The benefits of managing forest stand under the CCF systems include but not limited to improve ecological resilience, maintain the biodiversity of habitats, enhance the stands capacity to resist climate change, improve carbon sequestration potential, aesthetic and recreational value etc. (Guldin, 2011; von Gadow et al., 2012; Schütz et al., 2012). Despite the importance of the CCF system, the system has not been applied to the forest ecosystems of Nigeria.

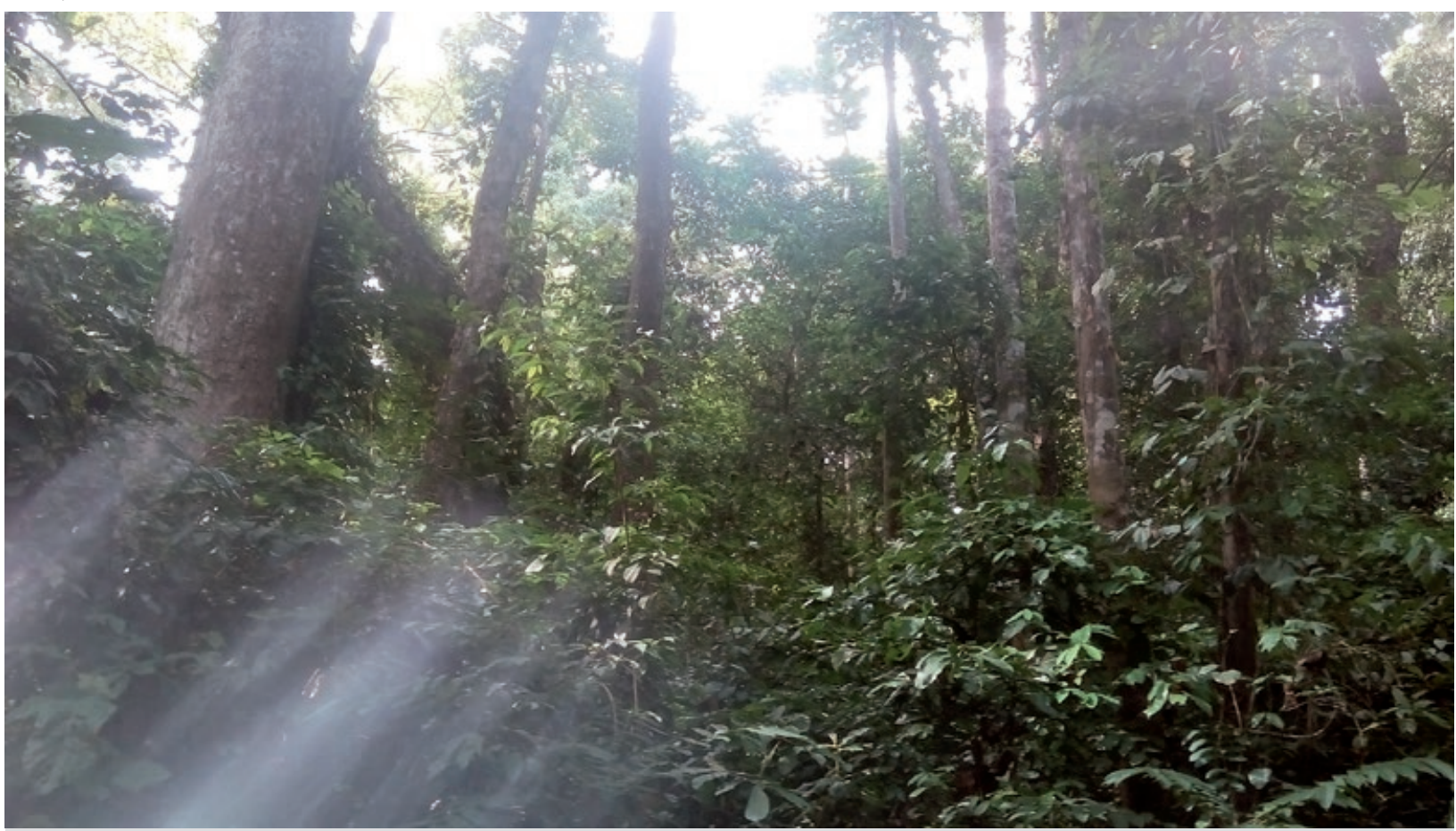

Photo 2.

Tropical mixed forest ecosystem in Nigeria.

Photo F. N. Ogana.

The selection method in the CCF systems can best be achieved with the $B D q$ method (Guldin, 1991). The "BDq method refers to the stand structure that can be uniquely determined for any combination of residual basal area (B), maximum retained diameter class (D), and negative exponential constant between diameter classes (q)" (Guldin, 1991). Under the $B D q$ method, the harvest is quantified by specifying values for the residual basal area $(B)$, maximum diameter $(D)$ and the $q$-factor $(q)$. The $B, D$ and $q$ parameters are then used to derive the target (ideal) stand (Graz and von Gadow, 2005; Guldin, 1991). The distribution of the target stand is then compared to the actual stand; and harvest (allowable cut) is prescribed by the difference between the two stands (Guldin, 1991). Harvest is only permitted for those trees that exceed the diameter distribution of the target stand. The $B D q$ has been consistently used in the management of uneven-aged stands in different parts of the world (Guldin, 1991; Baker et al., 1996; Cancino and von Gadow, 2002; Graz and von Gadow, 2005; Brzeziecki and Kornat, 2011; Drozdowski et al., 2014; Sharma et al., 2014).

To date, there is neither any proper management system nor silvicultural treatment been carried out in the complex tropical mixed stands in Nigeria. It is expected that the use of the $B D q$ method will help to sustain production, protection and conservation in the complex tropical mixed forest ecosystem of the region. Therefore, the main objective of this study is to evaluate the use of $B D q$ method in the management of the complex mixed stand in Nigeria. 


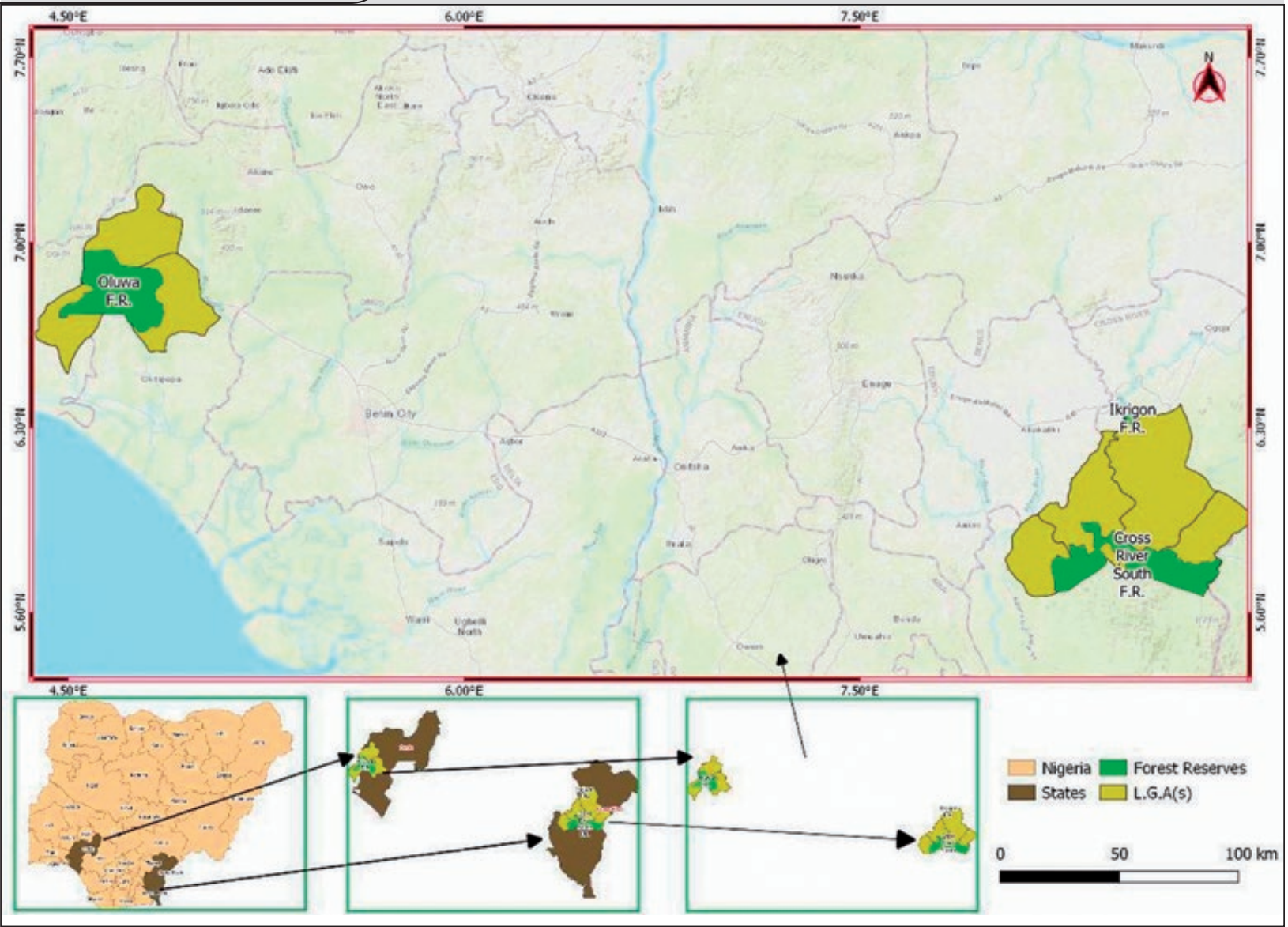

Figure 1.

Location of stratum 1 which consisted of 15 plots systematically demarcated in Ikrigon and Cross River State Forest Reserves (Ikrigon+CRSFR) and stratum 2 comprised of 7 plots demarcated in the natural stand of Oluwa Forest Reserve, Ondo State.

\section{Methodology}

Data

The data for the study were collected from two strata located in Cross River State and Ondo State of Nigeria. Both states are within the tropical rain forest zone of the country. Stratum 1 consisted of 15 plots systematically demarcated in Ikrigon and Cross River State Forest Reserves (Ikrigon+CRSFR). Whilst stratum 2 comprised of 7 plots demarcated in the natural stand of Oluwa Forest Reserve, Ondo State (see figure 1). Each plot has an area of 0.25 ha (i.e., $50 \mathrm{~m} \times 50 \mathrm{~m}$ ). Systematic sampling technique was used for the sample plots. Trees within each plot were identified and enumerated by expert taxonomist to the species level. Flora of West Tropical Africa (Hutchinson et al., 2014) was used for the authentication of the identified species. Only trees with diameter at breast height $(\mathrm{d}) \geq 10.0 \mathrm{~cm}$ that were considered in this study. Diameters at base and breast of individual tree were measured using a diameter tape while the measurement of tree height was achieved using a vertex. Important stand variables such as the number of trees per ha, basal area per ha, quadratic mean diameter, volume per ha and aboveground biomass in tonnes per ha were computed from the data sets (table I). The individual tree volume was estimated using the volume equations developed for tropical forest trees in Nigeria by Akindele and LeMay (2006). The pan tropical aboveground biomass equation (Chave et al., 2014) was used to estimate the tree biomass. The biomass function requires diameter, height and wood density as input variables. Wood density of individual tree species was retrieved from the global wood density database (Zanne et al., 2009).

Before the application of the $B D q$ method, the tree species were classified as timber, non-commercial timber and trees for fruits. The $B D q$ method was then applied to the timber species. A list of the commercial timber species is presented in the appendix (tables A.1. and A.2.).

\section{Tree diameter characterisation}

\section{Fitting the 3-parameter Weibull function (3P-Weibull)}

The 3-parameter Weibull function (3P-Weibull) was used to describe the diameter distribution of the timber species in the complex mixed tropical forest ecosystems. This model is simple and flexible and is more suitable than the 2-parameter Weibull function for describing theoretical uneven-aged (or irregular) truncated stands, namely with a minimum diameter inventory. The probability density function ( $p d f$ ) and cumulative distribution function (cdf) are expressed as (Gorgoso-Varela and Rojo-Alboreca, 2014): 
$f(x)=\frac{\alpha}{\beta}\left(\frac{x-\gamma}{\beta}\right)^{\alpha-1} e\left[-\left(\frac{x-\gamma}{\beta}\right)^{\alpha}\right]$

$F(x)=1-e\left[-\left(\frac{x-\gamma}{\beta}\right)^{\alpha}\right]$

where $f(x)$ is the relative frequency of tree; $x$ represents the continuous random variable (i.e., tree diameter); $\alpha$ is the shape parameter $(\alpha>0) ; \beta$ represents the scale parameter $(\beta>0) ; \gamma$ is the location parameter. Three frequently used methods were used to fit the 3P-Weibull to the individual plot data from both zones: maximum likelihood (ML), moments (MOM) and percentile. A general adjustment was used for all methods by taking the location $(\gamma)$ as the minimum observed tree diameter in each plot due the suitability of this value for theoretical distributions with "J reversed" shape.

\section{Maximum likelihood (ML) estimation}

The ML estimator defined by equations (3) and (4) was used to estimate the shape and scale parameter of the 3P-Weibull. This method was recently used by Gorgoso-Varela et al. (2020):

$\frac{\sum_{i=1}^{n}\left(x_{i}\right)^{\alpha} \ln \left(x_{i}-\gamma\right)}{\sum_{i=1}^{n}\left(x_{i}-\gamma\right)^{\alpha}}-\frac{1}{\alpha}=\frac{1}{n} \sum_{i=1}^{n}\left(x_{i}-\gamma\right) \quad[3]$

$\beta=\left(\frac{1}{n} \sum_{i=1}^{n}\left(x_{i}-\gamma\right)^{\alpha}\right)^{\frac{1}{\alpha}}$

where $x$ represents tree diameter and $n$ is the number observation in a plot. The LIFEREG procedure in SAS/STATTM (SAS Institute Inc., 2004) was used to estimate the shape and scale parameters.

\section{Moments}

This method is based on the relationship between the parameters of 3P-Weibull and the first and second diameter moment i.e., arithmetic mean and variance, respectively; expressed as equation (5) and (6). This method was recently used by other researchers (Gorgoso-Varela et al., 2020; Pogoda et al., 2020; Sun et al., 2019):

$\beta=\frac{\bar{d}-\gamma}{\Gamma\left(1+\frac{1}{\alpha}\right)}$

$\sigma^{2}=\frac{(\bar{d}-\gamma)^{2}}{\Gamma^{2}\left(1+\frac{1}{\alpha}\right)}\left[\Gamma\left(1+\frac{2}{\alpha}\right)-\Gamma^{2}\left(1+\frac{1}{\alpha}\right)\right]$

where $y$ represents the location parameter - taken as the smallest diameter of the plot (i.e., $10 \mathrm{~cm}$ ); $\bar{d}$ is the arithmetic mean diameter; $\sigma^{2}$ is the variance and $\Gamma(\bullet)$ is the gamma function. The bisection iterative procedure (Gerald and Wheatley, 1989) was used to solve equations (5) and (6) in SAS/STAT ${ }^{\mathrm{TM}}$ (SAS Institute Inc., 2004).

\section{Percentile}

This method is based on the relationship between the parameters of 3P-Weibull and the diameter percentiles. The Dubey (Dubey, 1967) percentile method was used in this study. In this method the scale $(\beta)$ and shape $(\alpha)$ parameters of the 3P-Weibull function were estimated with the following equations:

$\beta=P_{63}-\gamma[7]$

$\alpha=\frac{\ln \left[\frac{\ln (1-r)}{\ln (1-t)}\right]}{\ln \left[\frac{p_{r}-\gamma}{p_{t}-\gamma}\right]}$

Table I.

Descriptive statistics of the stand variables from the two strata.

\begin{tabular}{|c|c|c|c|c|c|c|}
\hline Strata & Statistics & $\underset{\text { (trees/ha) }}{\mathrm{N}}$ & $\underset{\left(\mathrm{m}^{2} / \mathrm{ha}\right)}{\mathbf{G}}$ & $\begin{array}{l}\mathrm{Dg} \\
(\mathrm{cm})\end{array}$ & $\begin{array}{c}V \\
\left(m^{3} / h a\right)\end{array}$ & $\underset{\text { (tons/ha) }}{\mathbf{W}}$ \\
\hline \multirow[t]{4}{*}{1 (15 plots) } & Mean & 282 & 24.1 & 32.6 & 515 & 238 \\
\hline & SD & 78 & 9.1 & 3.5 & 209 & 71 \\
\hline & Minimum & 168 & 11.0 & 27.3 & 195 & 121 \\
\hline & Maximum & 440 & 40.9 & 39.6 & 919 & 372 \\
\hline \multirow[t]{4}{*}{2 (7 plots) } & Mean & 278 & 19.8 & 29.9 & 390 & 162 \\
\hline & SD & 57 & 6.5 & 2.4 & 163 & 73 \\
\hline & Minimum & 200 & 14.5 & 27.2 & 267 & 98 \\
\hline & Maximum & 352 & 31.7 & 34.5 & 711 & 306 \\
\hline
\end{tabular}

N: number of trees per ha; G: basal area per ha; Dg: quadratic mean diameter; V: volume per ha; W: aboveground biomass; SD: standard deviation. 
where $P_{63}$ is the diameter corresponding to the 63rd percentile; $\gamma$ is location parameter; $r$ is equal $0.97 ; t$ is $0.17 ; p_{r}$ and $p_{t}$ represent the diameters corresponding to the 97th and 17 th percentiles, respectively.

\section{Evaluation statistics}

The consistency of the 3P-Weibull function fitted with ML, moments and percentile was evaluated with Kolmogorov-Smirnov statistic (Dn), Cramér-von Mises statistic $\left(\omega^{2}\right)$, mean square error (MSE) and bias. The smaller value of the evaluation of all statistics indicates a better fit:

$$
\begin{aligned}
& D n=\max \left\{\max _{1 \leq i \leq n_{i}}\left[F_{n}\left(x_{i}\right)-F_{0}\left(x_{j}\right)\right], \max _{1 \leq i \leq n_{i}}\left[F_{o}\left(x_{j}\right)-F_{n}\left(x_{i-1}\right)\right]\right\} \\
& \omega^{2}=\sum_{i=1}^{n}\left\{\hat{F}\left(x_{i}\right)-\frac{(i-0.5)}{n}\right\}^{2}+\frac{1}{12 n}[10] \\
& M S E=\frac{\sum_{i=1}^{n}\left(f\left(x_{i}\right)-f_{0}\left(x_{i}\right)\right)^{2}}{n} \quad[11] \\
& \text { Bias }=\frac{\sum_{i=1}^{n}\left(f\left(x_{i}\right)-f_{0}\left(x_{i}\right)\right)}{n} \quad[12]
\end{aligned}
$$

where $F(x)$ and $F_{0}(x)$ are the observed cumulative frequency distribution and theoretical cumulative frequency distribution, respectively; $x_{i}$ (in $\mathrm{cm}$ ) represents the diameter ( $i$ ranged from 1 to $n) ; n$ is the number of observations; $f\left(x_{i}\right)$ and $f_{0}\left(x_{i}\right)$ are the observed and predicted relative frequency of trees, respectively.

\section{The ideal irregular structures and the BDq method}

The diameter distribution of uneven-aged forests can be expressed as (Cancino and von Gadow, 2002):

$N_{i}=k_{0} e^{-k_{1} d_{i}} \quad[13]$

where $N_{i}$ represents the number of trees in ith diameter class; $d_{i}$ is the diameter class midpoint (in $\mathrm{cm}$ ); $k_{0}$ the intercept and $k_{1}$ represents the rate of change.

The constant rate of change between successive diameter class is defined by the quotient (q) (equation [14]). It provides information on the characteristics such as steepness or flatness of the inverse J-shaped distribution (Schütz et al., 2012):

$q=N_{i+1} / N_{i} \quad[14]$

Substituting $N_{i}$ of equation (13) into equation (14) will give equation (15):

$q=k_{0} e^{-k_{1}\left(d_{i}-w\right)} / k_{0} e^{-k_{1} d_{i}}$

$\therefore q=e^{-k_{1} w} \quad[16]$

where $w$ (in $\mathrm{cm}$ ) is the width of the diameter class. Other parameters are previously defined. From equation (14), $N_{i+1}$ can be defined as: $N_{i} \times q$. Thus, given a specific value of $q$ and with $N_{i+1}$ known, the number of trees in individual diameter class can be computed (Graz and von Gadow, 2005). This can be achieved with the general expression: $N_{i}=N_{1} \times q^{(i-1)}$ where $N_{1}$ is the number of trees in the largest diameter class (Cancino and von Gadow, 2002).
To quantify the available growing stock for the complex mixed tropical stands with a specified residual basal $\left(B, \mathrm{~m}^{2}\right)$ ha) the following expression that is based on diameter class midpoint $\left(d_{i}\right)$, was applied:

$B=K_{2} \sum_{i=1}^{n} N_{i} \times d_{i}^{2} ;$ where $K_{2}=\pi / 40000$

Substituting $N_{i}=N_{1} \times q^{(i-1)}$ into equation (17) give:

$B=K_{2} \sum_{i=1}^{n} N_{1} \times q^{(i-1)} \times d_{i}^{2}$

which when rearrange will give:

$B=N_{1} \times K_{2} \sum_{i=1}^{n} q^{(i-1)} \times d_{i}^{2} \equiv N_{1} \times K_{3} ;$ where $K_{3}=K_{2} \sum_{i=1}^{n} q^{(i-1)} \times d_{i}^{2}$

If $B=N_{1} \times K_{3}$; then $N_{1}=B / K_{3}$. Thus $K_{3}$ is also relevant in the computation of the diameter distributions.

Specifying the residual basal area $\left(B, \mathrm{~m}^{2} / \mathrm{ha}\right)$, maximum
diameter $(D, \mathrm{~cm})$ and $q$-ratio for the tropical mixed forest

Under the $B D q$ method, the harvest is often specified first by defining: the residual basal area per ha $\left(B, \mathrm{~m}^{2} / \mathrm{ha}\right)$, maximum diameter $(D, \mathrm{~cm})$ and $q$-ratio (i.e., the quotient). In this study, three $B D q$ regimes were evaluated for the tropical mixed forests based on the residual basal area $\left(B, \mathrm{~m}^{2} /\right.$ ha). Since there are no previous studies in this region to support the choice of residual basal, $B$ was intuitively set at 20,25 and $30 \mathrm{~m}^{2} /$ ha corresponding to heavy, medium and light-harvesting regimes, respectively. For beech (Fagus sylvatica L.) stands in Central Europe Schütz et al. (2016) proposed closely values of 20 and $24 \mathrm{~m}^{2} / \mathrm{h}$. The proportional residual basal area $B$ corresponding to the managed trees (timber species) was used for the calculations. This is to minimise overexploitation in as much only moderate allowable cut will be possible in the smaller diameter class. Since the minimum harvesting diameter for industrial roundwood is between 30 and $35 \mathrm{~cm}$ (Dupuy et al., 1999), the maximum diameter $(D)$ was set at $65 \mathrm{~cm}$ for the tropical forest. This is the diameter beyond which it is expected that a tree should not be considered for timber purpose. Such commercial timber trees with diameter $>D$, will be retained under the ecological system called "Green Tree Retention (GTR)" (Vanha-Majamaa and Jalonen, 2001). Other non-timber species such as Ricinodendron heudelotii (Baill.) Heckel, Parkia bicolor A. Chev., Diospyros crassiflora Hiern will also be managed under GTR.

The quotient $(q)$ was computed for each plot from the tropical forest data as the arithmetic mean of the values obtained from two successive diameter classes. A large value ( $\geq 1.69$ ) will yield a high ratio of small trees to larger ones - implies the production of smaller sawn-timber. Whilst a small value $(\leq 1.1)$ will produce a low ratio of small trees to larger ones - implies the production of larger sawn-timber (Guldin, 1991). 


\section{Application of the $B D q$ : the felling intensity (FI), volume $\left(V, \mathrm{~m}^{3} / \mathrm{ha}\right)$ and biomass $(W$, tons/ha) to extract}

Diameter distribution of the target (i.e., ideal) stand derived was compared by the $B D q$ parameters and the actual distribution derived from the inventory data. The difference between the two distributions was used to determine the number of trees per ha to extract from the stand (Guldin, 1991) and the corresponding volume and biomass. To ensure sustainability, the felling intensity (FI) was defined as:

$F I=\left\{\begin{array}{ccc}\frac{\sum_{i=1}^{n}\left(N_{i}-N_{(i+1) t}\right) P_{i}}{P_{t}} & ; & \text { if }\left(N_{i}-N_{(i+1) t}\right)>0 \\ 0 & ; & \text { Otherwise }\end{array}\right\}$

[20]

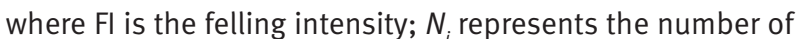
trees per ha in diameter class in actual diameter distribution; $N_{(i+1) t}$ number of trees per ha in diameter class directly higher to $i$ in the target (ideal) diameter distribution; $P_{i}$ represents the product (i.e., volume or biomass) of diameter class $i$ and $P_{t}$ represents the total actual products (volume or biomass).

\section{Results and discussion}

The descriptive statistics of the estimated location $(\gamma)$, scale $(\beta)$ and shape $(\alpha)$ parameters of the Weibull distribution by maximum likelihood, moments and percentiles are presented in table II. The computed Weibull location parameter was the same for all methods because the parameter was taken as the minimum observed diameter per inventory plot. The mean values of the location parameter for stratum 1 (Ikrigon+CRSFR) and stratum 2 (Oluwa FR) were 10.8467 and 10.4428 , respectively. This parameter marks the beginning of the diameter distribution. A similar adjustment has been used to achieve good performance with Weibull distribution in the tropical rain forest zone (Ogana et al., 2015; Ogana and Gorgoso-Varela, 2015). The estimated scale and shape parameters varied across the estimation methods. The values of the estimated parameters reflect an ideal structure of all-aged natural forest i.e., inverse J-shaped diameter distributions. Of the three parameters of the Weibull distribution, the shape parameter is the most important with respect to the $B D q$ method. This is based on the fact that it determines the shape of the diameter distributions. A value of $\alpha \leq 1$ produces an inverse J-shaped (Vinet and Zhedanov, 2011). The mean values of the shape parameter $(\alpha)$ for stratum 2 were within the limit $\alpha \leq 1$ especially, estimates from moments and percentile methods.

Table II.

Parameter values for the Weibull distribution fitted using three estimation methods.

\begin{tabular}{|c|c|c|c|c|c|c|}
\hline Strata & Method & Par. & Mean & SD & Minimum & Maximum \\
\hline \multirow[t]{9}{*}{$1(\mathrm{~N}=15)$} & \multirow[t]{3}{*}{$M L$} & V & 10.8467 & 1.0343 & 10.0000 & 14.0000 \\
\hline & & $\beta$ & 20.0789 & 4.1944 & 14.5138 & 29.7753 \\
\hline & & $\alpha$ & 1.2091 & 0.2410 & 0.8387 & 1.8861 \\
\hline & \multirow[t]{3}{*}{ Moment } & $y$ & 10.8467 & 1.0343 & 10.0000 & 14.0000 \\
\hline & & $\beta$ & 19.4796 & 4.5537 & 13.1217 & 29.7334 \\
\hline & & $\alpha$ & 1.1856 & 0.2818 & 0.8529 & 1.9288 \\
\hline & \multirow[t]{3}{*}{ Percentile } & $\gamma$ & 10.8467 & 1.0343 & 10.0000 & 14.0000 \\
\hline & & $\beta$ & 19.9762 & 5.8586 & 12.5420 & 31.3400 \\
\hline & & $\alpha$ & 1.1210 & 0.2448 & 0.7850 & 1.7595 \\
\hline \multirow[t]{9}{*}{$2(\mathrm{~N}=7)$} & \multirow[t]{3}{*}{$M L$} & $\gamma$ & 10.4428 & 0.3047 & 10.0000 & 10.9000 \\
\hline & & $\beta$ & 14.0344 & 1.9001 & 11.6868 & 17.6960 \\
\hline & & $\alpha$ & 1.0266 & 0.0905 & 0.8854 & 1.1814 \\
\hline & \multirow[t]{3}{*}{ Moment } & V & 10.4428 & 0.3047 & 10.0000 & 10.9000 \\
\hline & & $\beta$ & 12.9741 & 1.9798 & 10.7358 & 16.6752 \\
\hline & & $\alpha$ & 0.9303 & 0.1489 & 0.7180 & 1.1855 \\
\hline & \multirow[t]{3}{*}{ Percentile } & V & 10.4428 & 0.3047 & 10.0000 & 10.9000 \\
\hline & & $\beta$ & 11.5551 & 1.9195 & 9.6640 & 15.3800 \\
\hline & & $\alpha$ & 0.9870 & 0.1188 & 0.8604 & 1.1721 \\
\hline
\end{tabular}


Table III.

Characterisation of the natural mixed strata considering timber species according to shape parameter $\alpha$ of the Weibull distribution fitted by moments.

\begin{tabular}{|c|c|c|c|c|}
\hline Strata & $\begin{array}{c}\text { Uneven-aged } \\
(\boldsymbol{\alpha} \leq 1)\end{array}$ & $\begin{array}{c}\text { Two-aged } \\
(1<\boldsymbol{\alpha} \leq 1.35)\end{array}$ & $\begin{array}{c}\text { Even-aged } \\
(\boldsymbol{\alpha}>\mathbf{1 . 3 5})\end{array}$ & Total plots \\
\hline 1 & $6(40 \%)$ & $5(33.3 \%)$ & $4(26.7 \%)$ & 15 \\
\hline 2 & $6(85.7 \%)$ & $1(14.3 \%)$ & $0(0 \%)$ & 7 \\
\hline
\end{tabular}

\section{Table IV.}

Mean values of Kolmogorov-Smirnov statistic $(D n)$, Cramér-von Mises statistic $\left(\omega^{2}\right)$, Mean Squared Error (MSE) and bias.

\begin{tabular}{|c|c|c|c|c|c|}
\hline Strata & Method & $D_{n}$ & $\omega^{2}$ & MSE & bias \\
\hline \multirow[t]{3}{*}{1} & $M L$ & 0.105788 & 0.096385 & 0.000332 & 0.000186 \\
\hline & Moment & 0.105100 & 0.082868 & 0.000339 & 0.000173 \\
\hline & Percentile & 0.110735 & 0.147039 & 0.000324 & 0.000824 \\
\hline \multirow[t]{3}{*}{2} & $M L$ & 0.115378 & 0.110994 & 0.000283 & 0.000262 \\
\hline & Moment & 0.121492 & 0.079650 & 0.000311 & 0.000396 \\
\hline & Percentile & 0.122601 & 0.119634 & 0.000294 & 0.000610 \\
\hline
\end{tabular}

Characterisation of the natural stand strata considering timber species according to the shape parameter $(\alpha)$ of the Weibull distribution fitted by moments showed that $40 \%$ of the plots was classified as uneven-aged $(\alpha \leq 1)$, $33.3 \%$ as two-aged i.e., "semi-regular" $(1<\alpha \leq 1.35)$ and $26.7 \%$ as even-aged $(\alpha>1.35)$ in stratum 1 (Ikrigon+CSFR) (table III). However, in stratum 2 (Oluwa forest FR), 85.7\% of the plots were classified as uneven-aged and $14.3 \%$ as two-aged. No plot was in the class of even-aged. It is essential to recognise two-aged stands because they could be changed to uneven-aged without considerable alteration of their present structure.

The result of the evaluation statistics showed that the Weibull distribution fitted by maximum likelihood, moments and percentile performed better in the first stratum (Ikrigon+CRSFR) compared with the second stratum (Oluwa forest) (table IV). The Weibull distribution fitted by moments had the smallest Kolmogorov-Smirnov (Dn) (0.105100) statistic, Cramér-von Mises statistic $\left(\omega^{2}\right)(0.082868)$ and bias (0.000173) in stratum 1 (Ikrigon+CSFR) (table IV). It also presented the smallest Cramér-von Mises statistic $\left(\omega^{2}\right)(0.079650)$ in the second stratum. The Weibull distribution fitted with Maximum likelihood performed equally well, especially in the second stratum. The Weibull distribution fitted by percentile produced the poorest fits. The estimation method by moments remains one of the simplest procedures for estimating the parameters of the Weibull distributions. The variance and mean diameter required for using moments can be disaggregated from a yield table and apply. A parallel study by Sun et al. (2019) also reported good fit with the Weibull function fitted by moment for characterising diameter distributions in uneven-aged mixed stands of pine and oak. In Nigeria, Ogana (2020) also observed that using moment-based estimator to fit the Weibull distribution produced results comparable to other complex estimators. The author evaluated ten estimators used for the Weibull distribution in the study.

The line plots of the mean square error statistic describing the fit of the Weibull distribution fitted by ML, moments and percentile across the diameter classes are presented in figures 2 and 3 . The line patterns produced by the Weibull distribution fitted by the three methods were the same - characterised by increasing and decreasing behaviour. However, the MSE declined steadily in the larger diameter classes in both strata.

The mean statistics of the $q$-ratio for the total plots and the uneven-aged plots (i.e., plots considering timber species) in the two strata are shown in table V. The mean values of the $q$-ratio for the uneven-aged plots in stratum 1 and stratum 2 were 1.479 and 1.487 , respectively. The ratio will ensure the sustainable production of both sawn-timber in the mixed stands. Guldin (1991) asserted that a larger " $q$-ratio will steepen the ideal (target) distribution, retaining more small trees than larger ones and in consequence, increasing harvesting volume in the mixed stands". An ideal $q$-ratio could be intuitively chosen for a stand depending on the economic policy or management goal (Graz and von Gadow, 2005). However, it is more suitable to compute $q$-ratio for the individual plot, such a procedure will improve accuracy and provide flexibility.

The results of a simulated logging by applying the three regimes of $B D q$ to the two strata in which the maximum diameter $(D)$ was set at $65 \mathrm{~cm}$ and $q$-ratio derived by plot is shown in table $\mathrm{VI}$. The three regimes specified were heavy $\left(20 \mathrm{~m}^{2} / \mathrm{ha}\right)$, medium $\left(25 \mathrm{~m}^{2} / \mathrm{ha}\right)$ and light $\left(30 \mathrm{~m}^{2} / \mathrm{ha}\right)$. For each regime and stratum, the ideal basal area per ha applied $\left(B_{\text {applied }}\right)$ was lower compared with the specification for that regime. The values only correspond to the quantity of timber species in the stratum. Only timber species are managed under the $B D q$ method; whilst some species will be retained as GTR, including non-timber and fruit trees. If a heavy $B D q$ regime is to be considered for the uneven-aged plots in stratum 1 , the number of trees per ha to extract $\left(N_{\text {ex }}\right)$ is 28.56 $\mathrm{N} /$ ha with corresponding volume $\left(V_{\text {exx }}\right)$ and biomass $\left(W_{\text {exx }}\right)$ of $62.30 \mathrm{~m}^{3} /$ ha and 29.82 tons/ha, respectively. The required felling intensities in \% volume and biomass of the total of the managed species $\left(F I_{M}\right)$ will be 18.18 and 15.95 , respectively. In the case of stratum 2 using heavy $B D q$ regime, 


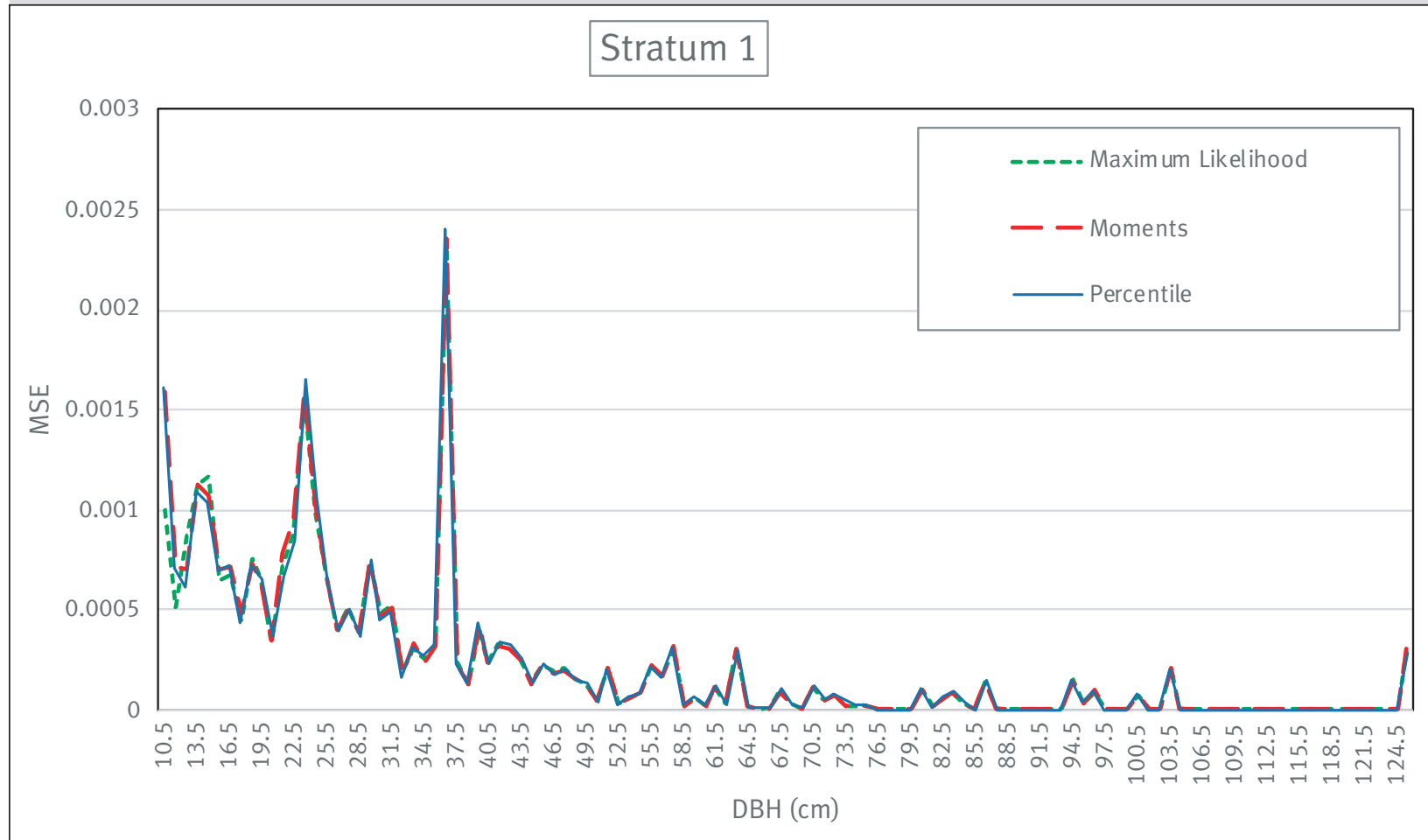

Figure 2.

Behaviour of the MSE for the fits by maximum likelihood, moments and percentile in each diameter class for stratum 1.

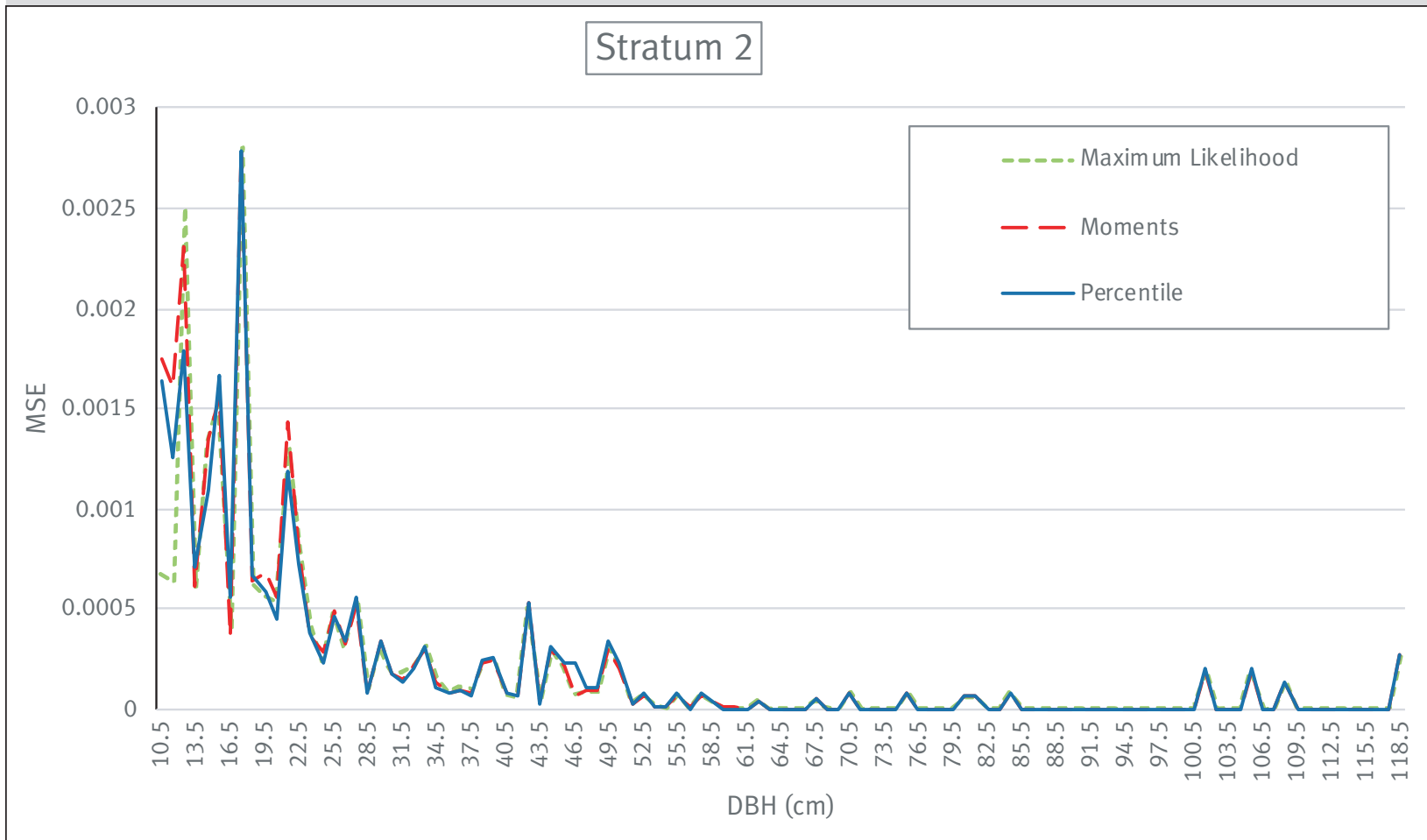

Figure 3.

Behaviour of the MSE for the fits by maximum likelihood, moments and percentile in each diameter class for stratum 2. 
Table V.

Mean statistics of the $q$ factor for total plots and uneven-aged plots in both strata.

\begin{tabular}{|c|c|c|c|c|}
\hline Strata & Mean & SD & Maximum & Minimum \\
\hline 1 (total plots) & 1.479 & 0.150 & 1.750 & 1.200 \\
\hline 1 (uneven-aged plots) & 1.479 & 0.171 & 1.678 & 1.200 \\
\hline 2 (total plots) & 1.489 & 0.137 & 1.778 & 1.361 \\
\hline 2 (uneven-aged plots) & 1.487 & 0.149 & 1.778 & 1.361 \\
\hline
\end{tabular}

$N_{\text {ext }}$ will equal to $34.60 \mathrm{~N} /$ ha and will yield $V_{\text {ext }}$ and $W_{\text {ext }}$ of $51.33 \mathrm{~m}^{3} /$ ha and 24.68 tons/ha, respectively. The $\mathrm{FI}_{M}$ for volume and biomass in the simulated logging will be 17.57 and 17.50 , respectively. To our knowledge, this is the first application of the $B D q$ method to a complex mixed tropical forest ecosystem, especially in Nigeria.

The graph of the observed and target (ideal) diameter distributions of timber species derived by the applying three regimes of $B$, with $D=65 \mathrm{~cm}$ and $q$ computed for each plot in the two strata is presented in figure 4 . Four representative plots (2 each from stratum 1 and stratum 2) with the highest density were used. From stratum 1 , plot 4 with a $q$ factor $=1.43$, harvesting is only possible in diameter classes of $37.5,47.5$ and $52.5 \mathrm{~cm}$. The commercial timber species in those classes are Cola gigantea A. Chev., and Gmelina arborea Roxb. Other commercial timber species such as Dialium pachyphyllum Harms, Dialium guineense Willd. could also be harvested in the stratum (plot 6). The commercial timber such as Albizia perrieri (Drake) R. Vig., Afzelia africana Sm., Dialium guineense Willd., Milicia excelsa (Welw.) C.C. Berg and Pterocarpus santalinoides DC. with diameter above $\mathrm{D}$, together with other non-timber species will constitute part of the GTR. Few timber species are available for harvest in stratum 2. Some timber species in the lower diameter class of 22.5 and $27.5 \mathrm{~cm}$ could also be harvested for other purposes (e.g. pole) under heavy and medium regimes (treatments) except in stratum 2 plot 1 . List of timber species in those classes include Pterygota bequaertii De Wild., Celtis zenkeri Engl., Bombax buonopozense P. Beauv., Terminalia superba Engl. \& Diels, Picralima nitida (Stapf) T. Durand \& H. Durand, Milicia excelsa (Welw.) C.C. Berg, Triplochiton scleroxylon K. Schum., Malacantha alnifolia (Baker) Pierre, Cedrela odorata L., Cleistopholis patens (Benth.) Engl. \& Diels, Antiaris toxicaria Lesch., and Hannoa klaineana Pierre ex Engl.

Adoption of the $B D q$ selection method will ensure sustainable management of the mixed stands. And as part of the CCF systems, the method will enhance the stands' capacity to resist climate change, improve carbon sequestration potential, promote better biodiversity of habitats, etc. (Schütz et al., 2012).

\section{Table VI.}

Mean values in each stratum after application of three regimes of the $B D q$ method for $D=65 \mathrm{~cm}$ and $q$ calculated by plot.

\begin{tabular}{|c|c|c|c|c|c|c|c|c|c|}
\hline Strata & Regime & $\begin{array}{c}\mathrm{B}_{\text {Total }} \\
\left(\mathrm{m}^{2 /} / \mathrm{ha}\right)\end{array}$ & $\begin{array}{c}\text { B }_{\text {applied }} \\
\left(m^{2 / h a}\right)\end{array}$ & $\begin{array}{c}\mathbf{N}_{\text {ext }} \\
\text { (Pies/ha) }\end{array}$ & $\underset{\left(m^{3 / h a}\right)}{V_{\text {ext }}}$ & $\begin{array}{l}\mathrm{FI}_{M} \\
(\% \mathrm{~V})\end{array}$ & $\begin{array}{l}\mathrm{Fl}_{\mathrm{T}} \\
(\% \mathrm{~V})\end{array}$ & $\begin{array}{c}\mathrm{W}_{\text {ext }} \\
\text { (tons/ha) }\end{array}$ & $\begin{array}{c}\mathrm{FI}_{M} \\
(\% W)\end{array}$ \\
\hline \multirow[t]{3}{*}{1 (total plots) } & Heavy & 20 & 15.52 & 69.43 & 190.66 & 37.19 & 30.94 & 82.05 & 36.53 \\
\hline & Medium & 25 & 19.41 & 52.94 & 166.11 & 31.47 & 26.20 & 70.77 & 30.77 \\
\hline & Light & 30 & 23.29 & 41.99 & 147.07 & 27.15 & 22.59 & 62.32 & 26.47 \\
\hline \multirow[t]{3}{*}{1 (uneven-aged plots) } & Heavy & 20 & 15.52 & 28.56 & 62.30 & 18.18 & 14.62 & 29.82 & 15.95 \\
\hline & Medium & 25 & 19.41 & 15.55 & 47.65 & 13.68 & 10.98 & 22.22 & 11.63 \\
\hline & Light & 30 & 23.29 & 9.84 & 39.94 & 11.22 & 8.88 & 18.46 & 9.40 \\
\hline \multirow[t]{3}{*}{2 (total plots) } & Heavy & 20 & 14.69 & 30.36 & 44.74 & 15.70 & 11.69 & 21.56 & 15.72 \\
\hline & Medium & 25 & 18.37 & 18.66 & 33.84 & 11.34 & 8.79 & 15.97 & 11.14 \\
\hline & Light & 30 & 22.04 & 12.49 & 26.09 & 8.59 & 6.77 & 12.14 & 8.34 \\
\hline \multirow[t]{3}{*}{2 (uneven-aged plots) } & Heavy & 20 & 14.69 & 34.60 & 51.33 & 17.57 & 13.32 & 24.68 & 17.50 \\
\hline & Medium & 25 & 18.37 & 21.77 & 39.48 & 13.23 & 10.26 & 18.63 & 12.99 \\
\hline & Light & 30 & 22.04 & 14.57 & 30.44 & 10.02 & 7.90 & 14.16 & 9.73 \\
\hline
\end{tabular}

B: residual basal area for the commercial managed species; $\mathrm{N}_{\text {ext }}$ : number of trees to extract; $\mathrm{V}_{\text {ext }}$ : volume to extract; $\mathrm{FI}_{\mathrm{M}}$ : felling intensity in \% volume and biomass of the total of the managed species; $\mathrm{Fl}_{\mathrm{T}}$ : felling intensity in \% of the total volume of species in the stratum (timber, non-timber and trees for fruits); $W_{\text {ext }}$ : biomass to extract. 

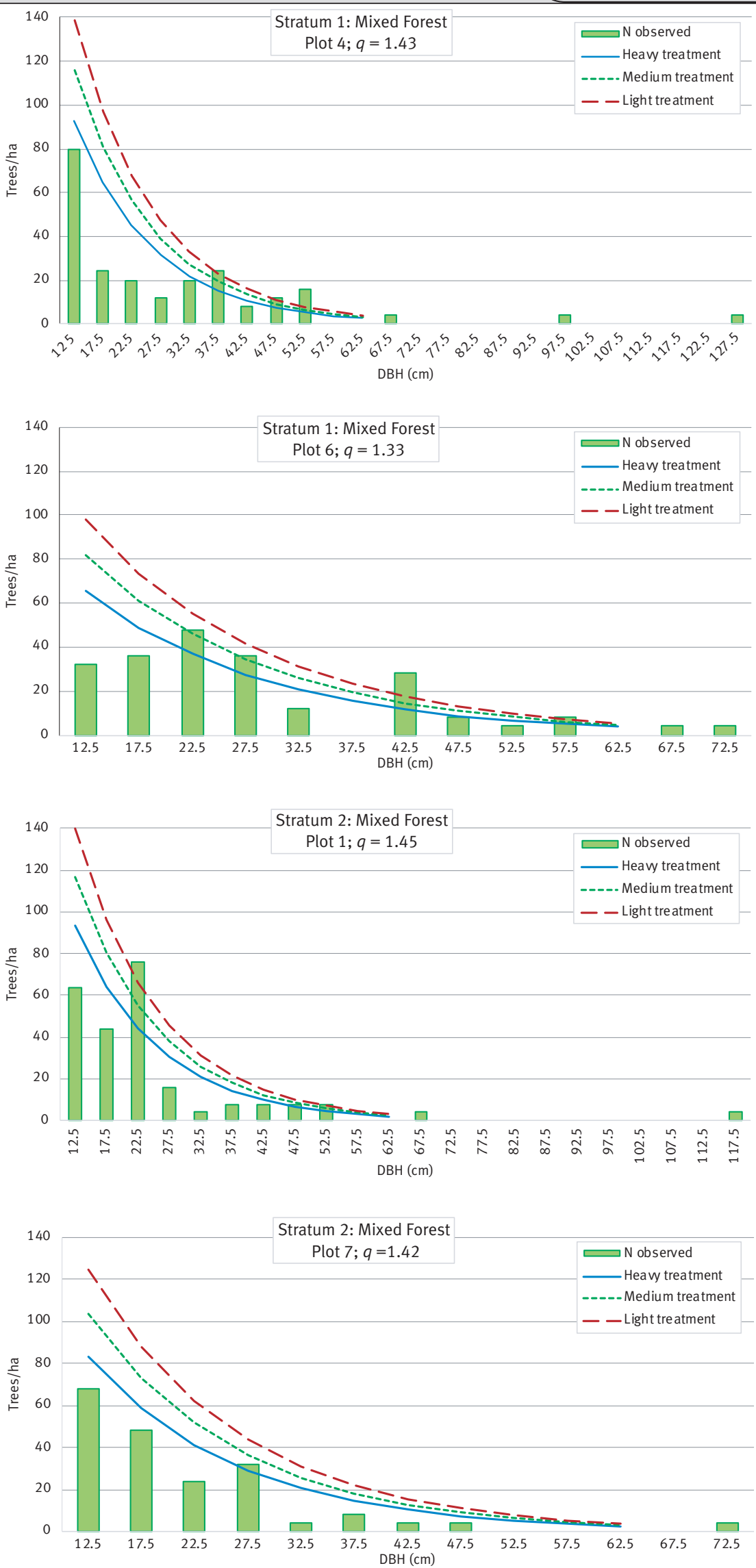

Figure 4.

Observed and ideal diameter distributions of timber species derived by applying $B D q$ method for three values of $B$, $D=65 \mathrm{~cm}$ and $q$ computed for the individual plots in the two strata. 


\section{Appendice}

Table A.1.

Commercial timber species in stratum 1.

\begin{tabular}{|c|c|c|c|}
\hline $\mathbf{S} / \mathbf{N}$ & Species & $\mathbf{S} / \mathbf{N}$ & Species \\
\hline 1 & Afzelia africana & 26 & Dialium guineense \\
\hline 2 & Albizia gummifera & 27 & Dialium pachyphyllum \\
\hline 3 & Albizia lebbeck & 28 & Distemonanthus benthamianus \\
\hline 4 & Albizia perrieri & 29 & Dracaena mannii \\
\hline 5 & Albizia zygia & 30 & Entandrophragma cylindricum \\
\hline 6 & Allanblackia floribunda & 31 & Funtumia africana \\
\hline 7 & Alstonia boonei & 32 & Funtumia elastica \\
\hline 8 & Anthocleista vogelii & 33 & Gmelina arborea \\
\hline 9 & Antiaris toxicaria & 34 & Gossweilerodendron balsamiferu \\
\hline 10 & Baillonella toxisperma & 35 & Hylodendron gabunense \\
\hline 11 & Barteria nigritana & 36 & Khaya grandifoliola \\
\hline 12 & Berlinia confusa & 37 & Khaya ivorensis \\
\hline 13 & Blighia sapida & 38 & Klainedoxa gabonensis \\
\hline 14 & Borassus aethiopium & 39 & Lannea welwitschii \\
\hline 15 & Brachystegia nigerica & 40 & Lophira alata \\
\hline 16 & Carapa procera & 41 & Lovoa trichilioides \\
\hline 17 & Ceiba petandra & 42 & Margaritaria discoidea \\
\hline 18 & Celtis zenkeri & 43 & Milicia excelsa \\
\hline 19 & Chrysophyllum giganteum & 44 & Musanga cecropioides \\
\hline 20 & Cleistopholis patens & 45 & Pausinystalia talbotii \\
\hline 21 & Coelocaryon preussii & 46 & Pentaclethra macrophylla \\
\hline 22 & Cola gigantea & 47 & Pentadesma butyracea \\
\hline 23 & Combretodendron macrocarpum & 48 & Pierreodendron africanum \\
\hline 24 & Cylicodiscus gabunnesis & 49 & Piptadeniastrum africanum \\
\hline 25 & Daniella ogea & 50 & Pseudospondias microcarpa \\
\hline
\end{tabular}

S/N Species

51 Pterocarpus mibreadii

52 Pterocarpus osun

53 Pterocarpus santalinoides

54 Pterocarpus soyauxi

55 Pterygota macrocarpa

56 Pycnanthus angolensis

57 Spathodea campanulata

58 Staudtia stipitata

59 Sterculia setigera

60 Strombosia pustulata

61 Symphonia globulifera

62 Tectona grandis

63 Terminalia superba

64 Tetrapleura tetraptera

65 Treculia obovoidea

66 Uapaca guineensis

67 Uapaca staudtii

68 Xylopia aethiopica

69 Zanthoxylum zanthoxyloides

Table A.2.

Commercial timber species in stratum 2.

\begin{tabular}{|c|c|c|c|}
\hline $\mathbf{S} / \mathbf{N}$ & Species & $S / N$ & Species \\
\hline 1 & Afzelia bipindensis & 22 & Lovoa trichilioides \\
\hline 2 & Albizia ferruginea & 23 & Malacantha alnifolia \\
\hline 3 & Anthocleista djalonensis & 24 & Mansonia altissima \\
\hline 4 & Antiaris toxicaria & 25 & Maranthes robusta \\
\hline 5 & Bombax buonopozense & 26 & Milicia excelsa \\
\hline 6 & Brachystegia eurycoma & 27 & Mitragyna stipulosa \\
\hline 7 & Carapa procera & 28 & Musanga cecropioides \\
\hline 8 & Cedrela odorata & 29 & Nesogordonia papaverifera \\
\hline 9 & Ceiba pentandra & 30 & Pausinystalia talbotii \\
\hline 10 & Celtis zenkeri & 31 & Picralima nitida \\
\hline 11 & Cleistopholis patens & 32 & Pterygota bequaertii \\
\hline 12 & Cordia millenii & 33 & Pterygota macrocarpa \\
\hline 13 & Distemonanthus benthamianus & 34 & Pycnanthus angolensis \\
\hline 14 & Entandrophragma angolense & 35 & Staudtia stipitata \\
\hline 15 & Entandrophragma cylindricum & 36 & Sterculia rhinopetala \\
\hline 16 & Ficus mucuso & 37 & Sterculia tragacantha \\
\hline 17 & Funtumia elastica & 38 & Strombosia pustulata \\
\hline 18 & Guarea cedrata & 39 & Terminalia superba \\
\hline 19 & Hannoa klaineana & 40 & Triplochiton scleroxylon \\
\hline 20 & Khaya ivorensis & 41 & Uapaca heudelotii \\
\hline
\end{tabular}




\section{Conclusion}

This study has successively applied the $B D q$ method to the complex mixed tropical forests of Nigeria. Harvest in the stands was defined using three regimes of residual basal area $\left(20,25\right.$ and $30 \mathrm{~m}^{2} / \mathrm{ha}$ ) with desirable felling intensities that would ensure the sustainability of the timber species. The number of trees to extract from the stand and the corresponding volume and aboveground biomass by using the $B D q$ method were rational. Commercial timber species with a diameter greater than the $65 \mathrm{~cm}$, together with other non-timber and trees for fruits will comprise the GTR system. Thus, with the adoption of $B D q$ method more attractive stand will be produced.

\section{Funding}

This research did not receive any specific grant from funding agencies in the public, commercial, or not-for-profit sectors.

\section{References}

Akindele S. O., LeMay V. M., 2006. Development of tree volume equations for common timber species in the tropical rain forest area of Nigeria. Forest Ecology and Management, 226 (1-3): 41-48. https://doi.org/10.1016/i. foreco.2006.01.022

Baker J. B., Cain M. D., Guldin J. M., Murphy P. A., Shelton M. G., 1996. Uneven-aged silviculture for the loblolly and shortleaf pine forest cover types. In: General Technical Report Southern Research Station, USDA Forest Service, S0-118: iv, 65 p. U.S. Department of Agriculture, Forest Service, Southern Forest Experiment Station. https://doi.org/10.2737/ so-gtr-118

Brzeziecki B., Kornat A., 2011. Application of the BDq method in uneven-aged stands silviculture. Sylwan, 155 (9): 589-598. https://www.cabdirect.org/cabdirect/abstract/20113395708

Cancino J., von Gadow K., 2002. Stem number guide curves for uneven-aged forests development and limitations. In: von Gadow K., Nagel J., Saborowski J. (eds). Continuous Cover Forestry. Managing Forest Ecosystems, vol. 4, 163-174. Dordrecht, Netherlands, Springer. https://doi. org/10.1007/978-94-015-9886-6 13

Chave J., Réjou-Méchain M., Búrquez A., Chidumayo E., Colgan M. S., Delitti W. B. C., et al., 2014. Improved allometric models to estimate the aboveground biomass of tropical trees. Global Change Biology, 20 (10): 3177-3190. https:// doi.org/10.1111/gcb.12629

Davies O., Haufe J., Pommerening A., 2008. Silvicultural principles of continuous cover forestry: a guide to best practice. Forestry Commission Wales, England, 111 p.
Drozdowski S., Bielak K., Buraczyk W., Gawron L., Jaros R., Zybura H., 2014. Silvicultural planning in complex structures of silver fir by means of the BDq method in Zagnańsk Forest District. Sylwan, 158 (9): 651-660. https://www. researchgate.net/profile/Stanislaw Drozdowski2/ publication/286935815 Silvicultural planning in complex structures of silver fir by means of the $\mathrm{BDq}$ method in Zagnansk Forest District/links/ 56715f2408ae0d8b0cc2f0a0.pdf

Dubey S. D., 1967. Some Percentile Estimators for Weibull Parameters. Technometrics, 9 (1): 119-129. https://doi.org/ 10.1080/00401706.1967.10490445

Dupuy B., Maitre H.-F., Amsallem I., 1999. Tropical forest management techniques: a review of the sustainability of forest management practices in tropical countries. Working Paper, FAO/FPIRS/04. http://www.fao.org/3/a-x4110e.pdf von Gadow K., Zhang C. Y., Wehenkel C., Pommerening A., Corral-Rivas J., Korol M., et al., 2012. Forest Structure and Diversity. In: Pukkala T., von Gadow K. (eds). Continuous Cover Forestry. Managing Forest Ecosystems, vol. 23, 29-83. Dordrecht, Netherlands, Springer. https://doi. org/10.1007/978-94-007-2202-6 2

Gerald C. F., Wheatley P. O., 1989. Applied numerical analysis. 4th edition. Reading, MA, USA, Addison-Wesley Publishing Co.

Gorgoso-Varela J. J., Rojo-Alboreca A., 2014. Use of Gumbel and Weibull functions to model extreme values of diameter distributions in forest stands. Annals of Forest Science, 71: 741-750. https://doi.org/10.1007/s13595-014-0369-1

Gorgoso-Varela J. J., Ogana F. N., Ige P. O., 2020. A comparison between derivative and numerical optimization methods used for diameter distribution estimation. Scandinavian Journal of Forest Research, 35 (3-4): 156-164. https://doi. org/10.1080/02827581.2020.1760343

Graz F. P., von Gadow K., 2005. Application of a 'stem number guide curve' for sustainable harvest control in the dry woodland savanna of northern Namibia. Southern African Forestry Journal, 204 (1): 37-44. https://doi. org/10.2989/10295920509505225

Guldin J. M., 1991. Uneven-aged BDq regulation of Sierra Nevada mixed conifers. Western Journal of Applied Forestry, 6 (2): 27-32. https://doi.org/10.1093/wjaf/6.2.27

Guldin J. M., 2011. Experience with the selection method in pine stands in the southern United States, with implications for future application. Forestry, 84 (5): 539-546. https://doi. org/10.1093/forestry/cpr035

Hutchinson J., Datziel J. M., Keay R. W. J., Hepper F. N., 2014. Flora of West Tropical Africa. Vol.1, Part 2. London, UK, Royal Botanical Gardens, Kew, 330 p.

Mason B., Kerr G., Simpson J., 1999. What is continuous cover forestry? Forestry Commission Information, Note 29. Forestry Commission, Edinburgh. 
Ogana F. N., 2020. An evaluation of ten estimators for fitting two-parameter weibull function to Nigerian forest stands. Eurasian Journal of Forest Science, 8 (2): 129-139. https:// doi.org/10.31195/ejejfs.712992

Ogana F. N., Gorgoso-Varela J. J., 2015. Comparison of estimation methods for fitting Weibull distribution to the natural stand of Oluwa forest reserve, Ondo State, Nigeria. Journal of Research in Forestry, Wildlife and Environment, 7 (2): 81-90. https://www.ajol.info/index.php/irfwe/article/ view $/ 125077$

Ogana F. N., Osho J. S. A., Gorgoso-Varela J. J., 2015. Comparison of beta, gamma Weibull distributions for characterising tree diameter in Oluwa forest reserve, Ondo State, Nigeria. Journal of Natural Sciences Research, 5 (4): 28-36. https:// iiste.org/Journals/index.php/JNSR/article/view/20167

Pogoda P., Ochat W., Orzeł S., 2020. Performance of Kernel estimator and Johnson $\mathrm{S}_{\mathrm{B}}$ function for modeling diameter distribution of black alder (Alnus glutinosa (L.) Gaertn.) stands. Forests, 11 (6). https://doi.org/10.3390/F11060634

SAS Institute Inc., 2004. SAS/STAT 9.1 User's Guide (Vol. 1-7). Cary, NC, USA, SAS Institute Inc. https://www.scirp. org/(S(i43dyn45teexjx455qlt3d2q))/reference/ReferencesPapers.aspx?ReferencelD $=1625989$

Schütz J. P., Pukkala T., Donoso P. J., von Gadow K., 2012. Historical emergence and current application of CCF. In: Pukkala T., von Gadow K. (eds). Continuous Cover Forestry. Managing Forest Ecosystems, vol. 23, 1-28. Dordrecht, Netherlands, Springer. https://doi.org/10.1007/978-94007-2202-61

Schütz J. P., Saniga M., Diaci J., Vrska T., 2016. Comparing close-to-nature silviculture with processes in pristine forest: lessons from Central Europe. Annals of Forest Science, 73: 911-921. https://doi.org/10.1007/s13595-016-0579-9

Sharma A., Bohn K., Jose S., Cropper W. P., 2014. Converting even-aged plantations to uneven-aged stand conditions: A simulation analysis of silvicultural regimes with slash pine (Pinus elliottii Engelm.). Forest Science, 60 (5): 893-906. https://doi.org/10.5849/forsci.13-097

Sun S., Cao Q. V., Cao T., 2019. Characterizing diameter distributions for uneven-aged pine-oak mixed forests in the Qinling Mountains of China. Forests, 10 (7): 596. https:// doi.org/10.3390/f10070596

Temesgen H., Zhang C. H., Zhao X. H., 2014. Modelling tree height-diameter relationships in multi-species and multi-layered forests: A large observational study from Northeast China. Forest Ecology and Management, 316: 78-89. https://doi.org/10.1016/i.foreco.2013.07.035

Turner I. M., 2001. The Ecology of Trees in the Tropical Rain Forest. In: The Ecology of Trees. Cambridge Tropical Biology Series, Cambridge University Press, 298 p. https://doi. org/10.1017/cbo9780511542206

Vanha-Majamaa I., Jalonen J., 2001. Green tree retention in Fennoscandian forestry. Scandinavian Journal of Forest Research, 16 (1): 79-90. https://doi. org/10.1080/028275801300004433
Vinet L., Zhedanov A., 2011. A “missing” family of classical orthogonal polynomials. Journal of Physics A: Mathematical and Theoretical, 44: 085201. https://doi. org/10.1088/1751-8113/44/8/085201

Zanne A. E., Lopez-Gonzalez G., Coomes D. A., Ilic J., Jansen S., Lewis S. L., et al., 2009. Data from: Towards a worldwide wood economics spectrum. Global wood density database. Dryad, Dataset. https://doi.org/10.5061/dryad.234

Ogana et al. - Contribution des auteurs

\begin{tabular}{l|l|} 
Rôle du contributeur & Noms des auteurs \\
Conceptualization & F. N. Ogana \\
\hline Data Curation & F. N. Ogana \\
\hline Formal Analysis & J. J. Gorgoso-Varela \\
\hline Methodology & F. N. Ogana \\
\hline Resources & A. O. Onefeli \\
\hline Visualization & F. N. Ogana, J. J. Gorgoso-Varela \\
\hline $\begin{array}{l}\text { Writing - Original Draft } \\
\text { Preparation }\end{array}$ & F. N. Ogana \\
\hline $\begin{array}{l}\text { Writing - Review \& } \\
\text { Editing }\end{array}$ & J. J. Gorgoso-Varela, A. O. Onefeli \\
\hline
\end{tabular}

Bois et Forêts des Tropiques - Revue scientifique du Cirad (c) Bois et Forêts des Tropiques (c) Cirad
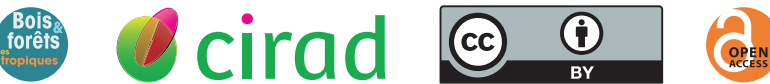

Cirad - Campus international de Baillarguet, 34398 Montpellier Cedex 5, France Contact : bft@cirad.fr - ISSN : L-0006-579X 